\title{
Advanced Catalysis in Hydrogen Production from Formic Acid and Methanol
}

\author{
Dmitri A. Bulushev (D)
}

Citation: Bulushev, D.A. Advanced Catalysis in Hydrogen Production from Formic Acid and Methanol. Energies 2021, 14, 6810. https:// doi.org/10.3390/en14206810

Received: 10 October 2021

Accepted: 13 October 2021

Published: 18 October 2021

Publisher's Note: MDPI stays neutral with regard to jurisdictional claims in published maps and institutional affiliations.

Copyright: (C) 2021 by the author. Licensee MDPI, Basel, Switzerland. This article is an open access article distributed under the terms and conditions of the Creative Commons Attribution (CC BY) license (https:// creativecommons.org/licenses/by/ $4.0 /)$.
Department of Nontraditional Catalytic Processes, Boreskov Institute of Catalysis SB RAS, 630090 Novosibirsk, Russia; dmitri.bulushev@catalysis.ru

\begin{abstract}
The Special Issue of the Energies journal related to the hydrogen production from formic acid decomposition was published recently by MDPI. This Editorial note contains a short analysis of the papers published in this Special Issue and some historical information connected to this reaction.
\end{abstract}

Keywords: formic acid; hydrogen production; catalysts

Hydrogen production from different hydrogen carriers is an important topic that has been examined in many studies, as hydrogen is considered to be a clean fuel for the future, giving only water as a product. At the same time, efforts for its storage and transportation may encounter serious difficulties related to safety. Hence, it is necessary to develop liquid and solid hydrogen carriers that will allow the safe storage/transportation of hydrogen and its liberation at mild conditions using catalysts. Therefore, many recent studies in this field have focused on the development of efficient catalysts for hydrogen production from different compounds.

MDPI published the Special Issue "Advanced Catalysis in Hydrogen Production from Formic Acid and Methanol" in the Energies journal and as a separate book, for which I served as Guest Editor. Formic acid and methanol are liquid organic hydrogen carriers (LOHCs) that can be produced from biomass [1] or by $\mathrm{CO}_{2}$ hydrogenation [2,3]. The Special Issue included five invited research papers and two invited reviews. Unfortunately, no papers related to the production of hydrogen from methanol were presented; hence, the issue was focused on different aspects of hydrogen production from formic acid using heterogeneous and homogeneous catalysts (Figure 1).

Studies of the catalytic decomposition of formic acid have more than 150 years of history and have contributed significantly to the science of catalysis. Formic acid decomposes through two routes, giving hydrogen and carbon dioxide (1, dehydrogenation) and carbon monoxide and water (2, dehydration).

$$
\begin{aligned}
& \mathrm{HCOOH} \rightarrow \mathrm{CO}_{2}+\mathrm{H}_{2} \\
& \mathrm{HCOOH} \rightarrow \mathrm{CO}+\mathrm{H}_{2} \mathrm{O}
\end{aligned}
$$

The German chemist Döbereiner was the first to report the dehydration of formic acid by heating it with anhydrous sulfuric acid in 1821 [4]. This reaction was studied in detail at the beginning of the last century. Some heterogeneous catalysts were tested. If the goal is to produce pure hydrogen, dehydration should be eliminated using catalysts. However, dehydration is important for applications where formic acid is applied as a CO source-for example, synthesis gas production $[1,5]$.

The French chemist Marcellin Berthelot was the first to report the dehydrogenation of formic acid in 1864 [6]. He conducted the decomposition of formic acid vapor over $15 \mathrm{~g}$ of Pt black powder at 443 and $533 \mathrm{~K}$ and showed that equal amounts of $\mathrm{CO}_{2}$ and $\mathrm{H}_{2}$ were formed. Later, the Nobel Prize Winner in Chemistry (1912) Paul Sabatier and his co-author A. Mailhe showed that some heterogeneous catalysts such as $\mathrm{Pt}, \mathrm{Pd}, \mathrm{Ni}, \mathrm{Cu}, \mathrm{Cd}, \mathrm{SnO}_{2}$, and 
$\mathrm{ZnO}$ were active in dehydrogenation reaction, while oxides of $\mathrm{Ti}, \mathrm{Al}, \mathrm{Si}, \mathrm{Zr}, \mathrm{U}$, and $\mathrm{W}$ were active in dehydration reaction [7]. Formaldehyde was also formed sometimes. It should be mentioned that Sabatier was an assistant in the laboratory of Berthelot and received his Doctor of Science degree under his supervision in 1880 [8].

\begin{tabular}{|c|c|c|c|c|c|c|}
\hline $\begin{array}{l}\text { Metal complexes } \\
\text { Stathi et al. }\end{array}$ & $\begin{array}{l}\text { Supported PdAg } \\
\text { catalysts } \\
\text { Navlani-Garcia et al. }\end{array}$ & $\begin{array}{c}\text { Supported Au } \\
\text { catalysts } \\
\text { Sobolev et al. }\end{array}$ & $\begin{array}{c}\text { Pt/N-CNTs } \\
\text { catalysts } \\
\text { Podyacheva et al. }\end{array}$ & $\begin{array}{c}\text { Pd/N-C catalysts } \\
\text { Golub et al. }\end{array}$ & $\begin{array}{l}\text { Ni/N-C catalysts } \\
\text { Nishchakova et al. }\end{array}$ & $\begin{array}{c}\mathrm{CuO}-\mathrm{CeO}_{2} / \mathrm{Al}_{2} \mathrm{O}_{3} \\
\text { catalyst } \\
\text { Pechenkin et al. }\end{array}$ \\
\hline
\end{tabular}

Figure 1. Catalysts for hydrogen production from formic acid decomposition considered in the Special Issue.

In 20th century, formic acid decomposition was studied as a model reaction used for the establishment of the bases of catalysis and for the development of spectroscopic methods. Later, Density Functional Theory (DFT) studies were performed to elucidate the mechanism of the reaction.

Formic acid contains a considerable amount of hydrogen $\left(53 \mathrm{~g} \mathrm{~L}^{-1}\right)$. Since $2008-2010$, it has been considered as a substance that could be used for hydrogen storage. Homogeneous catalysts have been used intensively for liquid-phase formic acid decomposition and for formic acid production from $\mathrm{CO}_{2}$ and $\mathrm{H}_{2}$ [9-14]. At the same time, heterogeneous catalysts have also been used for liquid-phase [15] and gas-phase [16,17] reactions with the purpose of producing $\mathrm{CO}$-free hydrogen efficiently. These catalysts possess a significant advantage with respect to homogeneous catalysts, allowing to separate them easily from the reaction mixture $[18,19]$.

There are several ways to achieve efficient hydrogen production from formic acid using catalysts. These involve support modification, metal size optimization, the alloying of active metal with another metal, and promotion with basic compounds containing alkali metals or amines. All these methods are considered in this Special Issue. The reviews featured to discuss liquid-phase formic acid decomposition over bimetallic (PdAg) [20], molecular ( $\mathrm{Ru}, \mathrm{Rh}, \mathrm{Ir}, \mathrm{Fe}, \mathrm{Co}$, and others) [21], and heterogenized molecular Fe catalysts [21]. The gas-phase reaction is studied over highly dispersed Pd [22], Pt [23], Au [24], Cu [25], and $\mathrm{Ni}[26]$-supported catalysts.

Stathi et al. [21], in their review, discuss the features of the production of hydrogen from formic acid over a set of homogeneous catalysts represented by metal complexes. The mechanism of the liquid phase reaction was analyzed based on DFT studies. The authors indicated the importance of the deprotonation of formic acid as a first step of the reaction. They also outlined other important factors: the nature of the solvent and ligand, temperature and $\mathrm{pH}$. Moreover, they discussed the continuous operation of hydrogen production from formic acid and showed some examples where immobilized molecular catalysts demonstrated comparable properties to nonimmobilized catalysts. This latter feature is important for the creation of immobilized molecular catalysts [18].

Navlani-García et al. [20], in their review, discussed the properties of PdAg catalysts in the production of hydrogen from formic acid. The interest in these catalysts is based on their high performance in liquid-phase reactions $[15,27,28]$. The authors ascribed the enhancement displayed by PdAg catalysts as compared to their monometallic counterparts to several effects, such as the formation of electron-rich Pd species and increased resistance to $\mathrm{CO}$ poisoning. Additionally, the authors considered the photocatalytic decomposition of formic acid. They also concluded that very little is known about the performance of the catalysts in highly concentrated formic acid solutions. It would be interesting to study the decomposition of gas-phase formic acid over highly dispersed PdAg catalysts.

The nature of the catalyst's support plays an important role in the reaction when the metal is highly dispersed. Sobolev et al. [24] studied the gas-phase formic acid decomposition over $\mathrm{Au}$ catalysts with a mean size of 1.6-2.4 nm supported on $\mathrm{SiO}_{2}, \mathrm{TiO}_{2}$, and $\mathrm{Al}_{2} \mathrm{O}_{3}$ and compared their catalytic properties with the properties of the corresponding supports. They concluded that the undesirable dehydration pathway was provided by the acid-base properties of the support. Thus, the selectivity in hydrogen production was 
found to be very low for the $\mathrm{Au} / \mathrm{TiO}_{2}$ catalyst (<20\%), but it was close to $100 \%$ for the $\mathrm{Au} / \mathrm{Al}_{2} \mathrm{O}_{3}$ catalyst. At the same time, the conversion of formic acid over the former catalyst was entirely provided by the support, since the conversion temperature dependences were almost the same. Earlier, we also indicated the importance of the nature of the support for highly dispersed Au catalysts and this reaction [29,30]. Gold supported on an N-doped porous carbon support showed a higher hydrogen yield than gold supported on silica or alumina.

In this Special Issue, the effect of carbon doping with nitrogen species was analyzed in detail for Pt [23], Pd [22], and Ni [26] catalysts. Nitrogen was inserted into the structure of carbon supports by direct synthesis using N-containing precursors $[23,26]$ or by the post-deposition of $\mathrm{N}$-containing precursors on the surface of the carbon support with optimized properties [22]. The latter method allows the scaling of the synthesis of N-doped carbon and could be useful for industrial applications.

It is important that the $\mathrm{N}$-doping of the carbon support exerts a significant promotional effect. One of the reasons for the high activity of N-doped catalysts is the improvement in metal dispersion and formation of single-atom metal sites stabilized by pyridinic $\mathrm{N}$ species present in the support [19]. For example, Podyacheva et al. [23] demonstrated the higher activity of single $\mathrm{Pt}$ atoms supported on N-doped carbon nanotubes or carbon nanofibers as compared to Pt atoms on the surface of Pt nanoparticles. A correlation with the concentration of pyridinic $\mathrm{N}$ atoms was shown. In a recent paper [31], this group demonstrated the same effects for Pd catalysts.

Golub et al. [22] used different N-containing precursors (bypiridine, phenanthroline, and melamine) to deposit over a graphitic carbon support (Sibunit). The best performance was discovered for Pd catalysts, for which melamine was used as the N-precursor. The deposition of melamine followed by pyrolysis led to an increase in the activity and selectivity and to a decrease in the apparent activation energy. Thus, the catalytic activity of the $\mathrm{N}$-doped Pd catalyst was higher by a factor of 4 than that of the Pd catalyst supported on the N-free carbon support at $373 \mathrm{~K}$.

The properties of non-noble metal catalysts ( $\mathrm{Ni}$ and $\mathrm{Cu}$ ) were also discussed in this Special Issue. Normally, the activity of these catalysts is lower than that of noble metals such as $\mathrm{Pt}$ and $\mathrm{Pd}$, but their price is also lower and this is important. Nishchakova et al. [26] studied Ni catalysts supported on N-doped and N-free porous carbon prepared at different temperatures. A temperature equal to $1073 \mathrm{~K}$ was found to be optimal for the catalytic activity. The N-doped Ni catalysts possessed a high stability in the formic acid decomposition reaction and a slightly higher activity than the $\mathrm{N}$-free catalyst, with a mean particle size of $3.9 \mathrm{~nm}$. A further study in this field [32] performed by the same group demonstrated that the used $\mathrm{N}$-doped catalyst was a single-atom catalyst with active $\mathrm{Ni}-\mathrm{N}_{4}$ sites.

Pechenkin et al. [25] used a $\mathrm{Cu}$-containing catalyst supported on a $\mathrm{CeO}_{2} / \gamma-\mathrm{Al}_{2} \mathrm{O}_{3}$ support. The gas-phase decomposition of formic acid was studied in detail. The authors showed a very high yield of hydrogen equal to $98 \%$ at temperatures of $473-573 \mathrm{~K}$. This yield was higher than those obtained for methanol and dimethoxymethane steam reforming reactions. The catalyst was stable in the reaction conditions used.

Therefore, key problems related to catalytic activity in hydrogen production from formic acid were discussed in this Special Issue. Interestingly, the amounts of noble metals in the $\mathrm{Pt}$ [23] and $\mathrm{Pd}$ [22] catalysts discussed in this issue were by a factor of $10^{5}$ lower than those used in the experiments carried out by Berthelot [6] at similar temperatures. This reflects the progress made in the development of catalysts during the last 150 years, indicating that modern catalysts are significantly more active.

Finally, the results reported in this Special Issue can be applied for the development of catalysts for hydrogen production not only from formic acid, but also from other organic hydrogen carriers. 
Funding: The preparation of this note is supported by the Russian Science Foundation (grant 17-73-30032).

Conflicts of Interest: The authors declare no conflict of interest.

\section{References}

1. Bulushev, D.A.; Ross, J.R.H. Towards sustainable production of formic acid. ChemSusChem 2018, 11, 821-836. [CrossRef]

2. Álvarez, A.; Bansode, A.; Urakawa, A.; Bavykina, A.V.; Wezendonk, T.A.; Makkee, M.; Gascon, J.; Kapteijn, F. Challenges in the greener production of formates/formic acid, methanol, and DME by heterogeneously catalyzed $\mathrm{CO}_{2}$ hydrogenation processes. Chem. Rev. 2017, 117, 9804-9838. [CrossRef]

3. Bulushev, D.A.; Ross, J.R. Heterogeneous catalysts for hydrogenation of $\mathrm{CO}_{2}$ and bicarbonates to formic acid and formates. Catal Rev. 2018, 60, 566-593. [CrossRef]

4. Schierz, E.R. The decomposition of formic acid by sulfuric acid1. J. Am. Chem. Soc. 1923, 45, 447-455. [CrossRef]

5. Albert, J.; Jess, A.; Kern, C.; Pöhlmann, F.; Glowienka, K.; Wasserscheid, P. Formic acid-based Fischer-Tropsch synthesis for green fuel production from wet waste biomass and renewable excess energy. ACS Sustain. Chem. Eng. 2016, 4, 5078-5086. [CrossRef]

6. Berthelot, M. Notes sur la decomposition de l'acide formique. C. R. Chim. 1864, 59, 901.

7. Sabatier, P.; Mailhe, A. Sur la decomposition catalytique de l'acide formique. C. R. Chim. 1911, 152, $1212-1215$.

8. Fechete, I. Paul Sabatier-The father of the chemical theory of catalysis. C. R. Chim. 2016, 19, 1374-1381. [CrossRef]

9. Joó, F. Breakthroughs in hydrogen storage-formic acid as a sustainable storage material for hydrogen. ChemSusChem 2008, 1 , 805-808. [CrossRef]

10. Boddien, A.; Loges, B.; Junge, H.; Beller, M. Hydrogen generation at ambient conditions: Application in fuel cells. ChemSusChem 2008, 1, 751-758. [CrossRef]

11. Fukuzumi, S. Bioinspired energy conversion systems for hydrogen production and storage. Eur. J. Inorg. Chem. 2008, 2008, 1351-1362. [CrossRef]

12. Enthaler, S. Carbon dioxide-The hydrogen-storage material of the future? ChemSusChem 2008, 1, 801-804. [CrossRef] [PubMed]

13. Himeda, Y. Highly efficient hydrogen evolution by decomposition of formic acid using an iridium catalyst with $4,4^{\prime}$-dihydroxy2,2'-bipyridine. Green Chem. 2009, 11, 2018-2022. [CrossRef]

14. Fellay, C.; Dyson, P.; Laurenczy, G. A viable hydrogen-storage system based on selective formic acid decomposition with a ruthenium catalyst. Angew. Chem. Int. Ed. 2008, 47, 3966-3968. [CrossRef] [PubMed]

15. Zhou, X.; Huang, Y.; Xing, W.; Liu, C.; Liao, J.; Lu, T. High-quality hydrogen from the catalyzed decomposition of formic acid by $\mathrm{Pd}-\mathrm{Au} / \mathrm{C}$ and Pd-Ag/C. Chem. Commun. 2008, 30, 3540-3542. [CrossRef] [PubMed]

16. Bulushev, D.; Beloshapkin, S.; Ross, J.R. Hydrogen from formic acid decomposition over Pd and Au catalysts. Catal. Today 2010, 154, 7-12. [CrossRef]

17. Solymosi, F.; Koós, Á.; Liliom, N.; Ugrai, I. Production of CO-free $\mathrm{H}_{2}$ from formic acid. A comparative study of the catalytic behavior of Pt metals on a carbon support. J. Catal. 2011, 279, 213-219. [CrossRef]

18. Bulushev, D. Progress in catalytic hydrogen production from formic acid over supported metal complexes. Energies 2021, 14, 1334. [CrossRef]

19. Bulushev, D.A.; Bulusheva, L.G. Catalysts with single metal atoms for the hydrogen production from formic acid. Catal. Rev. 2021, 1-40. [CrossRef]

20. Navlani-García, M.; Salinas-Torres, D.; Cazorla-Amorós, D. Hydrogen production from formic acid attained by bimetallic heterogeneous PdAg catalytic systems. Energies 2019, 12, 4027. [CrossRef]

21. Stathi, P.; Solakidou, M.; Louloudi, M.; Deligiannakis, Y. From homogeneous to heterogenized molecular catalysts for $\mathrm{H}_{2}$ production by formic acid dehydrogenation: Mechanistic aspects, role of additives, and co-catalysts. Energies 2020, 13, 733. [CrossRef]

22. Golub, F.S.; Beloshapkin, S.; Gusel'Nikov, A.V.; Bolotov, V.A.; Parmon, V.N.; Bulushev, D.A. Boosting hydrogen production from formic acid over Pd catalysts by deposition of N-containing precursors on the carbon support. Energies 2019, 12, 3885. [CrossRef]

23. Podyacheva, O.; Lisitsyn, A.; Kibis, L.; Boronin, A.; Stonkus, O.; Zaikovskii, V.; Suboch, A.; Sobolev, V.; Parmon, V. Nitrogen doped carbon nanotubes and nanofibers for green hydrogen production: Similarities in the nature of nitrogen species, metal-nitrogen interaction, and catalytic properties. Energies 2019, 12, 3976. [CrossRef]

24. Sobolev, V.; Asanov, I.; Koltunov, K. The role of support in formic acid decomposition on gold catalysts. Energies 2019, 12, 4198. [CrossRef]

25. Pechenkin, A.; Badmaev, S.; Belyaev, V.; Sobyanin, V. Production of hydrogen-rich gas by formic acid decomposition over $\mathrm{CuO}-\mathrm{CeO}_{2} / \gamma-\mathrm{Al}_{2} \mathrm{O}_{3}$ Catalyst. Energies 2019, 12, 3577. [CrossRef]

26. Nishchakova, A.D.; Bulushev, D.A.; Stonkus, O.A.; Asanov, I.P.; Ishchenko, A.V.; Okotrub, A.V.; Bulusheva, L.G. Effects of the carbon support doping with nitrogen for the hydrogen production from formic acid over Ni catalysts. Energies 2019, $12,4111$. [CrossRef]

27. Tedsree, K.; Li, T.; Jones, S.C.; Chan, C.W.A.; Yu, K.M.K.; Bagot, P.; Marquis, E.; Smith, G.D.W.; Tsang, S.C.E. Hydrogen production from formic acid decomposition at room temperature using a Ag-Pd core-shell nanocatalyst. Nat. Nanotechnol. 2011, 6, 302-307. [CrossRef] 
28. Navlani-García, M.; Mori, K.; Nozaki, A.; Kuwahara, Y.; Yamashita, H. Screening of carbon-supported PdAg nanoparticles in the hydrogen production from formic acid. Ind. Eng. Chem. Res. 2016, 55, 7612-7620. [CrossRef]

29. Zacharska, M.; Chuvilin, A.L.; Kriventsov, V.V.; Beloshapkin, S.; Estrada, M.; Simakov, A.; Bulushev, D.A. Support effect for nanosized Au catalysts in hydrogen production from formic acid decomposition. Catal. Sci. Technol. 2016, 6, 6853-6860. [CrossRef]

30. Bulushev, D.A.; Sobolev, V.I.; Pirutko, L.V.; Starostina, A.V.; Asanov, I.P.; Modin, E.; Chuvilin, A.L.; Gupta, N.; Okotrub, A.V.; Bulusheva, L.G. Hydrogen production from formic acid over Au catalysts supported on carbon: Comparison with Au catalysts supported on $\mathrm{SiO}_{2}$ and $\mathrm{Al}_{2} \mathrm{O}_{3}$. Catalysts 2019, 9, 376. [CrossRef]

31. Suboch, A.; Podyacheva, O. Pd catalysts supported on bamboo-like nitrogen-doped carbon nanotubes for hydrogen production. Energies 2021, 14, 1501. [CrossRef]

32. Bulushev, D.A.; Nishchakova, A.D.; Trubina, S.V.; Stonkus, O.A.; Asanov, I.P.; Okotrub, A.V.; Bulusheva, L.G. Ni-N 4 sites in a single-atom Ni catalyst on N-doped carbon for hydrogen production from formic acid. J. Catal. 2021, 402, 264-274. [CrossRef] 